AGH DRILLING, OIL, GAS • Vol. 29 • No. 2 • 2012

http://dx.doi.org/10.7494/drill.2012.29.2.375

\author{
Tomasz Śliwa*, Daniel Skowroński*, \\ Andrzej Gonet*, Aneta Sapińska-Śliwa*
}

\title{
ROCK MASS THERMAL ANALYSIS \\ IN UNDERGROUND THERMAL ENERGY STORAGE (UTES)**
}

\section{INTRODUCTION}

Underground thermal energy storage (UTES) is used in order to manage thermal energy in a reasonable way, especially in facilities where central heating and air conditioning are required. Figure 1 illustrates the visualization of UTES at the University of Ontario Institute of Technology in Canada. 213-metre deep borehole heat exchangers in the number of 362 have been carried out at the area of $128 \times 64 \mathrm{~m}$. Many existing wells in Poland can be adopt into borehole heat exchangers [4].

In the following dissertation, underground thermal energy and coolness storage made in Łódź has been analyzed [3]. It is based on 160 borehole heat exchangers of the total deepness of 16,000 metres. The total heating power of heat pumps which are used to heat and cool and which depend on borehole heat exchangers is $860 \mathrm{~kW}$.

The objective of the dissertation is the analysis of interaction between borehole heat exchangers in thermal energy storage during heating as well as cooling. The analysis has been carried out for verifying the following three theses:

1) Interaction between borehole heat exchangers determines the minimum distance between them. Five metres is not too short distance for BHE operating cyclically in a heating and cooling mode.

2) Differences in thermal conductance of geological layers do not have much influence on temperature distribution in underground thermal energy storage.

3) The deepness of borehole heat exchangers is theoretically limitless when borehole exchangers work solely in a thermal mode. If borehole heat exchangers work cyclically in a heating and cooling mode, the deepness of $100 \mathrm{~m}$ is not enough.

* AGH University of Science and Technology, Drilling, Oil and Gas Faculty, Krakow

** The paper realized within the Statutory Research Program at the Faculty of Drilling, Oil and Gas AGH University of Science and Technology in Krakow, no. 11.11.190.555 


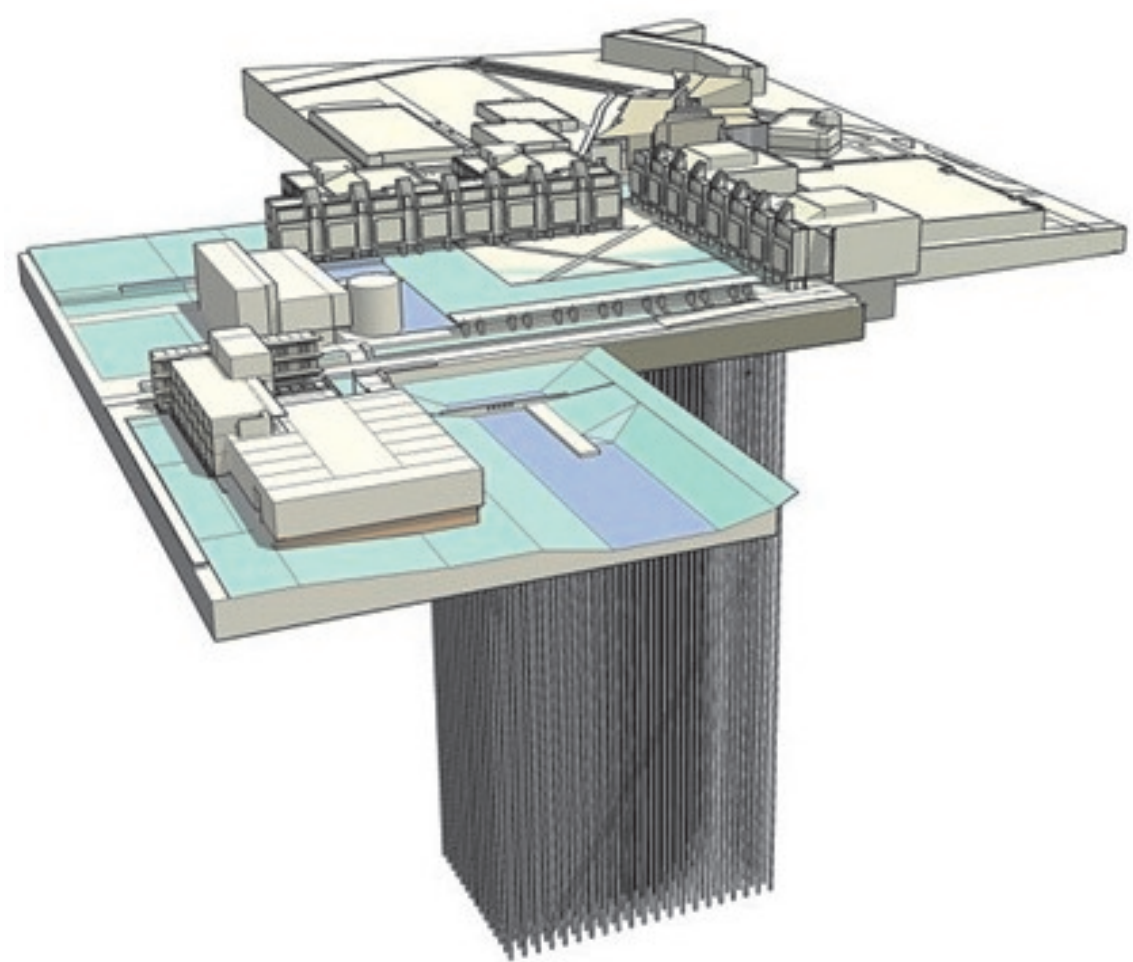

Fig. 1. The visualization of UTES at the University of Ontario Institute of Technology in Canada [1]

The research object consists of $160 \mathrm{BHE}$ «s with tge deep of $100 \mathrm{~m}$. Polythene (PE 100) U-tubes (Fig. 2) of $40 \mathrm{~mm}$ diameter are supposed to be exchangers. They have been tested for leakproof under pressure of $0.8 \mathrm{MPa}$. The leakproof test is conducted before and after placing an exchanger in a borehole. Termorotas is the material used to fill the space between rock mass and exchanger's pipes. Its application aims at improving the thermal inductance between rocks and thermal energy storage. It also counteracts decreasing heat flow that is exchanged in boreholes during their exploitation. What is more, the suspension is used to isolate aquifers.

A heating system which uses compressing pumps consists of three kinds of circulation:

- low-temperature heat source circulation,

- circulation of a thermodynamic agent in a heat pump,

- carrier's circulation in a heat consumer.

Underground thermal energy storage in rock mass functions as a low-temperature energy source. Heat pumps transform approximately $75 \%$ of energy gained from underground thermal energy storage, losing around $25 \%$ to drive energy which is, actually, electric energy in compressing heat pumps. 


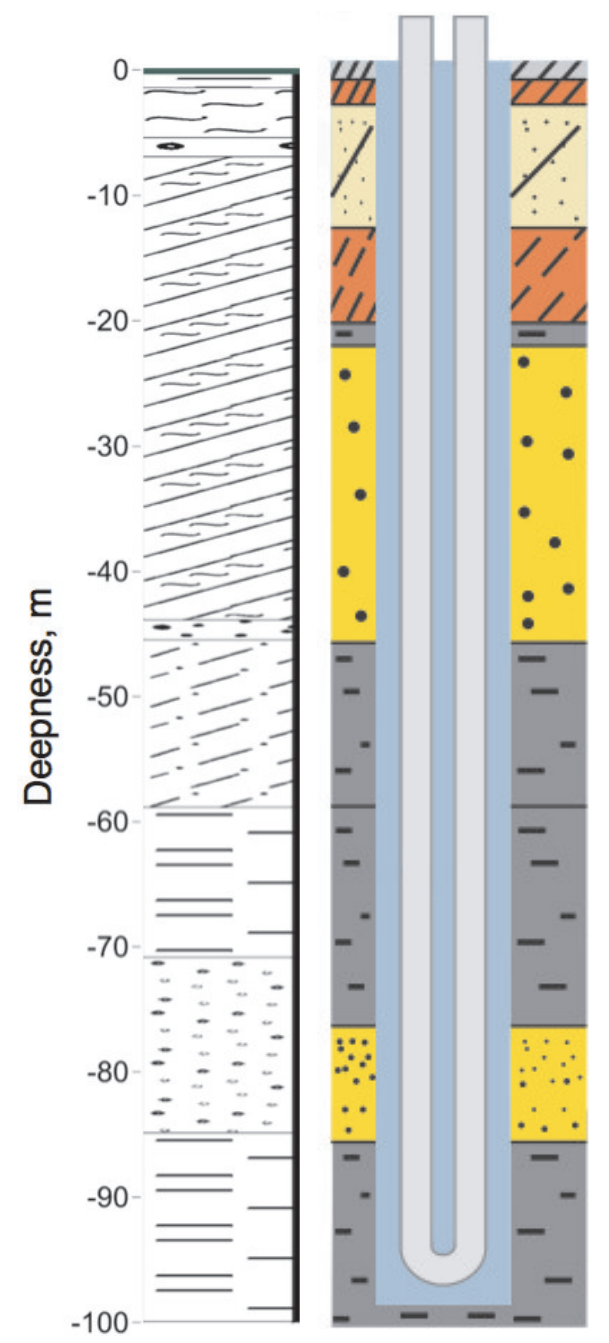

Fig. 2. A U-tube of a borehole heat exchanger with the lithological profile

\section{GEOLOGICAL STRUCTURE}

Figure 2 illustrates rock mass lithology determined in a borehole that has been carried out to place a U-tube of a heat exchanger. There have been found two aquifers. The more shallow aquifer happens to be in a thin layer of concrete grey all-ups and a deeper one in a layer of coarse-grained sands. The attention should be also drawn to heat conductance. The layer of coarse-grained sands provides heat conductance at the highest level. Table 1 illustrates a lithological profile and thermal properties of rocks in underground thermal energy storage in Łódź. 
Table 1

Thermal parameters of rocks in underground thermal energy storage in Łódź at Pabianicka Street

\begin{tabular}{|l|c|c|c|c|c|}
\hline \multicolumn{1}{|c|}{ Lithology } & $\begin{array}{c}\text { Depth } \\
\text { of roof } \\
{[\mathrm{MBGL}]}\end{array}$ & $\begin{array}{c}\text { Depth } \\
\text { of floor } \\
{[\mathrm{MBGL}]}\end{array}$ & $\begin{array}{c}\text { Thickness } m \\
{[\mathrm{~m}]}\end{array}$ & $\begin{array}{c}\text { Thermal } \\
\text { conductance } \lambda \\
{\left[\mathrm{W} \cdot \mathrm{m}^{-1} \cdot \mathrm{K}^{-1}\right]}\end{array}$ & $\begin{array}{c}\text { Volumetric heat } \\
\text { capacity } c_{V} \\
{\left[\mathrm{MJ} \cdot \mathrm{m}^{-3} \cdot \mathrm{K}^{-1}\right]}\end{array}$ \\
\hline mound & 0 & 1.5 & 1.5 & 0.4 & 1.5 \\
\hline concrete grey dust & 1.5 & 5.5 & 4 & 0.4 & 1.6 \\
\hline gravel & 5.5 & 7 & 1.5 & 1.1 & 1.5 \\
\hline silt & 7 & 44 & 37 & 1.6 & 1.6 \\
\hline concrete grey all-ups & 44 & 45.6 & 1.6 & 1.8 & 1.7 \\
\hline loam & 45.6 & 59 & 13.4 & 1.6 & 1.8 \\
\hline sludge & 59 & 71 & 12 & 2.2 & 1.6 \\
\hline coarse-grained sand & 71 & 85 & 14 & 2.4 & 1.7 \\
\hline sludge with wood pieces & 85 & 94 & 9 & 2.2 & 1.5 \\
\hline $\begin{array}{l}\text { sludge with limestone } \\
\text { pieces }\end{array}$ & 94 & 100 & 6 & 2.2 & 1.7 \\
\hline
\end{tabular}

\section{LOCATION OF BOREHOLE HEAT EXCHANGERS}

Borehole heat exchangers have been arranged in a radial arrangement in order to achieve evenly distributed flows in them (Fig. 3).

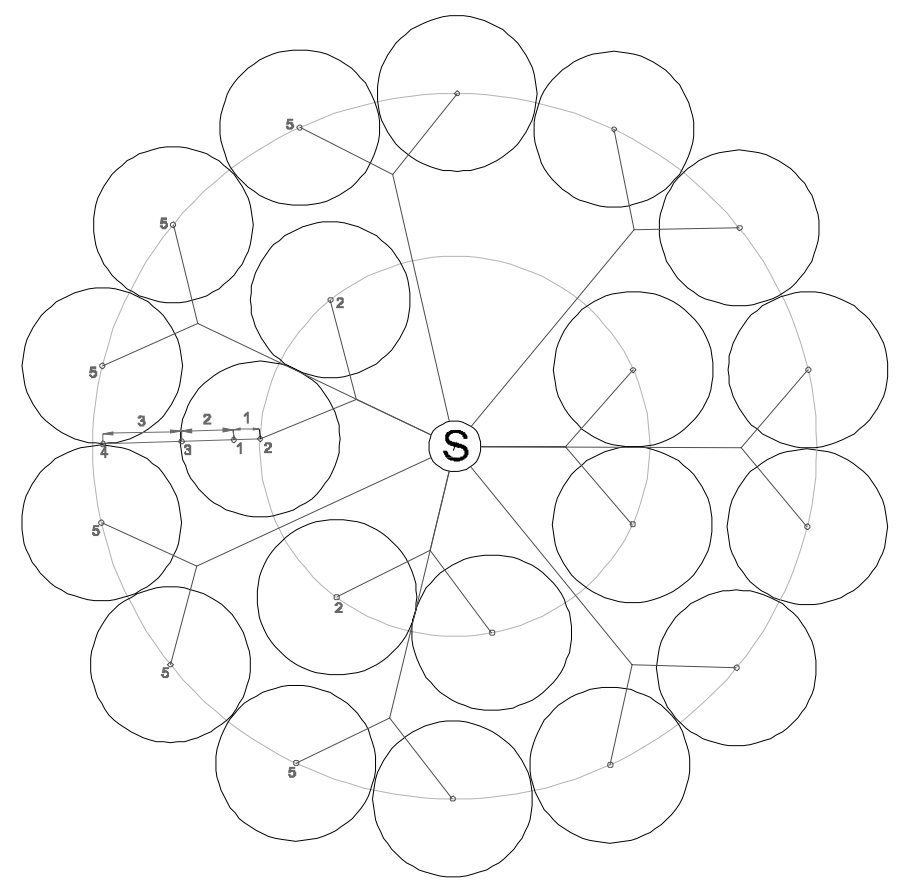

Fig. 3. An arrangement of borehole heat exchangers in a single cell consisting of 20 exchangers digit 2 is assigned to exchangers in the middle of internal circles and digit 5 is assigned to exchangers in the middle of external circles; $\mathrm{S}$ - collecting well (like in Figure 4) 
An arrangement of borehole heat exchangers in a single cell has been illustrated in Figure 4. An inside of a distributing well has been illustrated in Figure 5.

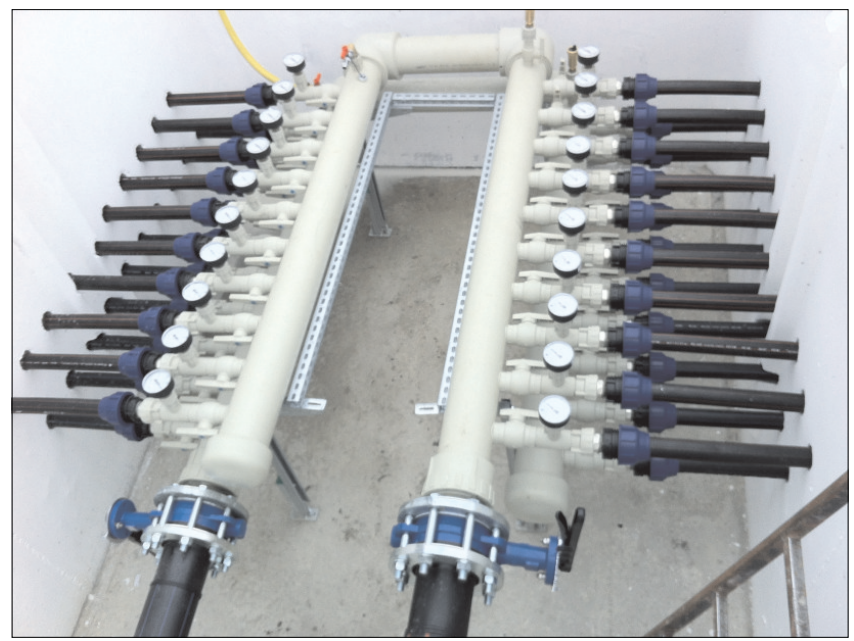

Fig. 4. Collector of 20 borehole heat exchangers

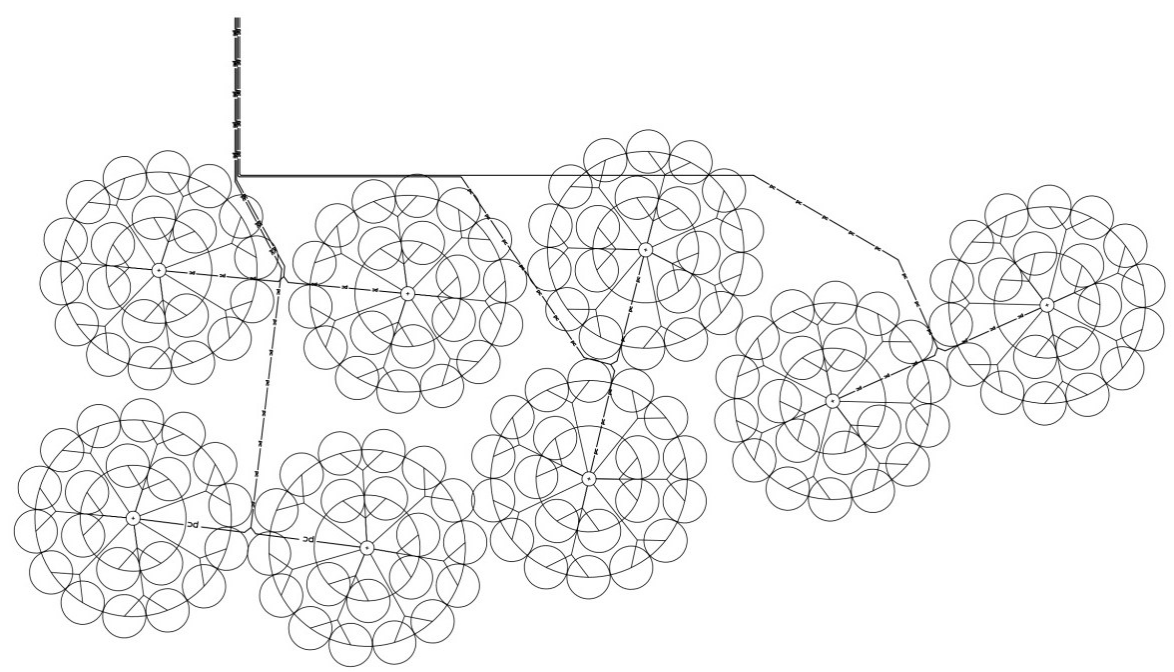

Fig. 5. Cells' arrangement of borehole heat exchangers, 160 boreholes altogether

\section{THERMAL ANALYSES IN BOREHOLES}

In order to conduct research, there have been drilled three boreholes marked by numbers 1,3 and 4 in Figure 6. 
There has been implemented a single tube to have a possibility of placing a thermometer in a 100-metre deep borehole in order to measure temperature. Temperature in a borehole has been assumed as the average of thermometer's indications. A measurement tube has been also placed in boreholes 2 and 5 while implementing U-tubes of a heat exchanger in them. Boreholes number 1 and 3 are adequately one and three metres away from a borehole heat exchanger. Measurements coming from two resisting boreholes (4 and 5) have been used to plot a chart of average temperature (Fig. 14). The measurements have been carried out from October 2009 to January 2012.

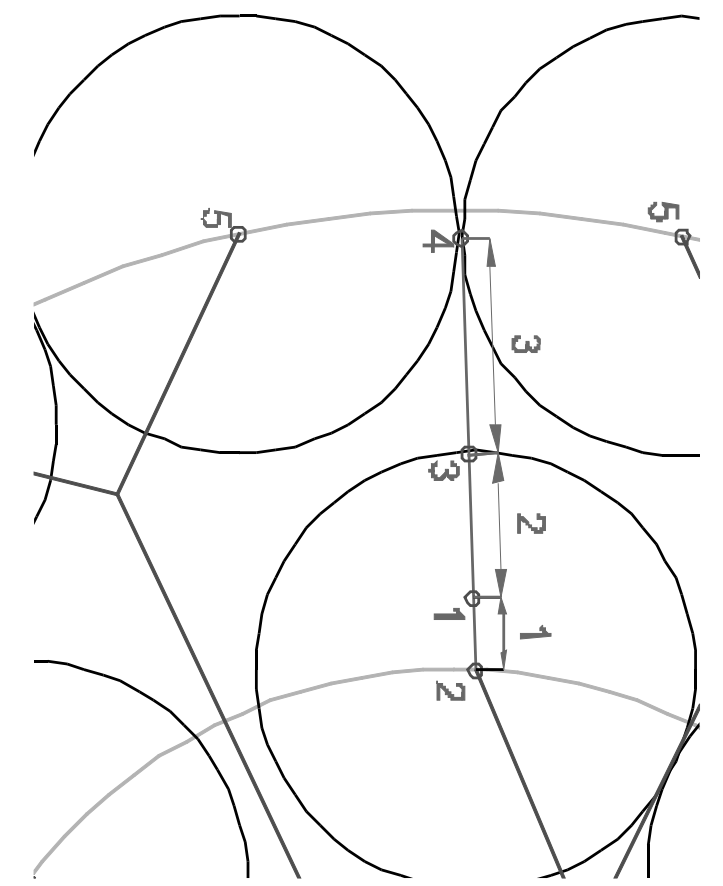

Fig. 6. Arrangement of borehole exchangers (points 2 and 5) and thermo-piezometers (points 1, 3 and 4)

Figure 7 illustrates a slide of an animation used for visualising the results taken from the measurements. The measurement was carried out in October 2009 and shows the natural condition of rock mass temperature before starting underground thermal energy storage exploitation. On the left side, there can be seen the lithology with the deepness attached. On the right side, there is a legend concerning the temperature. The whole has been made in the scale. A borehole heat exchanger (located in point 2) has been marked by a black thick line. The remaining two lines determine temperature in boreholes 1 and 3 (thermo-piezometers). Constant temperature has been applied at a 5-metre distance as in the case of Figure 7. On such an assumption, the measuring error will not be significant, in accordance with Figure 14 where there can be seen almost constant temperature in borehole 4 . 


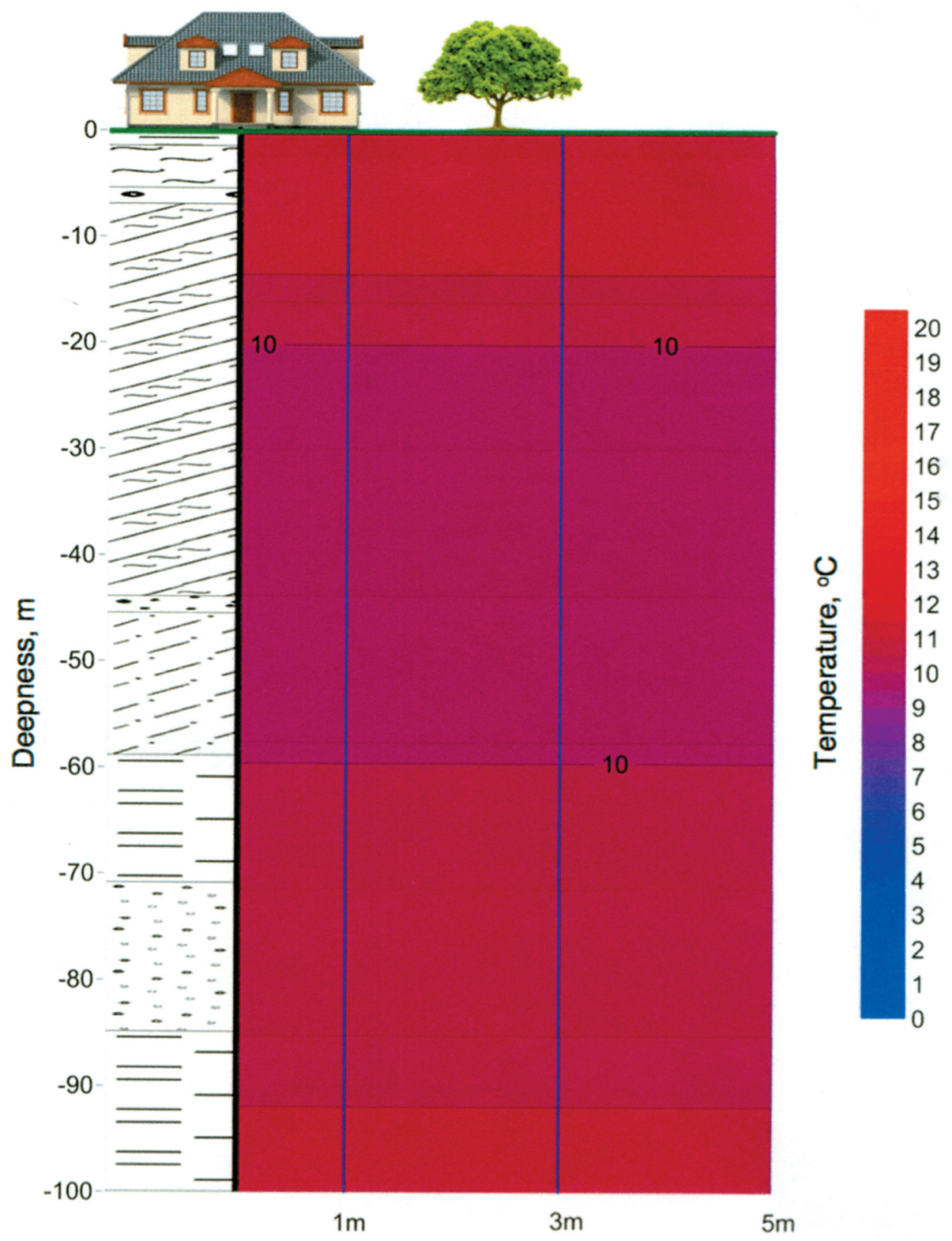

Fig. 7. Rock mass temperature in October 2009

Figure 8 illustrates a map from July. While conditioning the facility, huge amount of heat is delivered to rock mass. In the map, it can be noticed that the most intensive temperature change happens to be one metre away from a borehole exchanger. Temperature change is almost immeasurable three metres away from the exchanger's axis. 


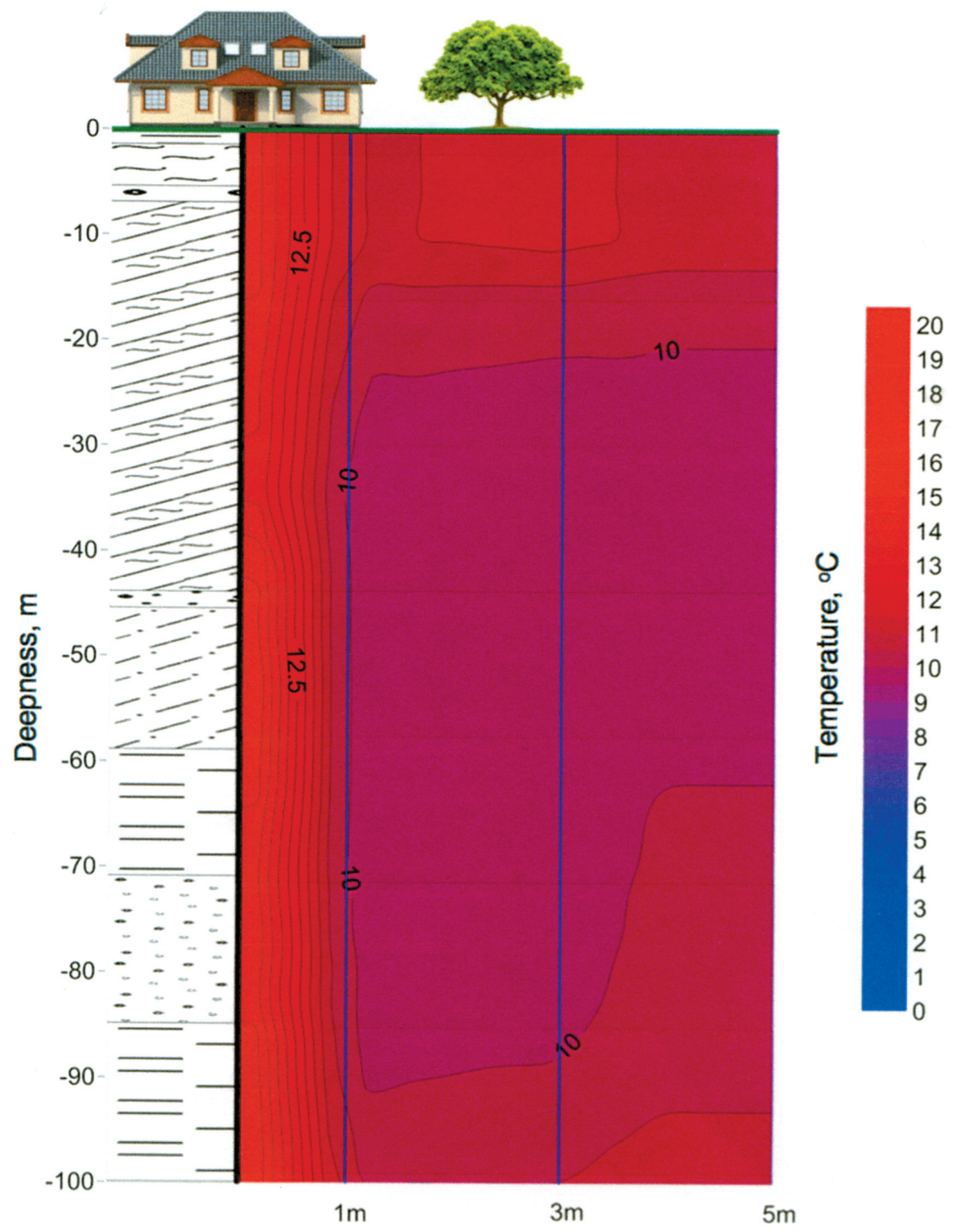

Fig. 8. Rock mass temperature in July 2010

Figure 9 illustrates a map from October 2010. On the basis of the outcoming results it can be stated that small differences in heat conductance of geological layers do not have greater influence on temperature distribution in rock mass. There is no visible intensive temperature change in layers which can be characterized by better heat conductance (in accordance with Table 1). 


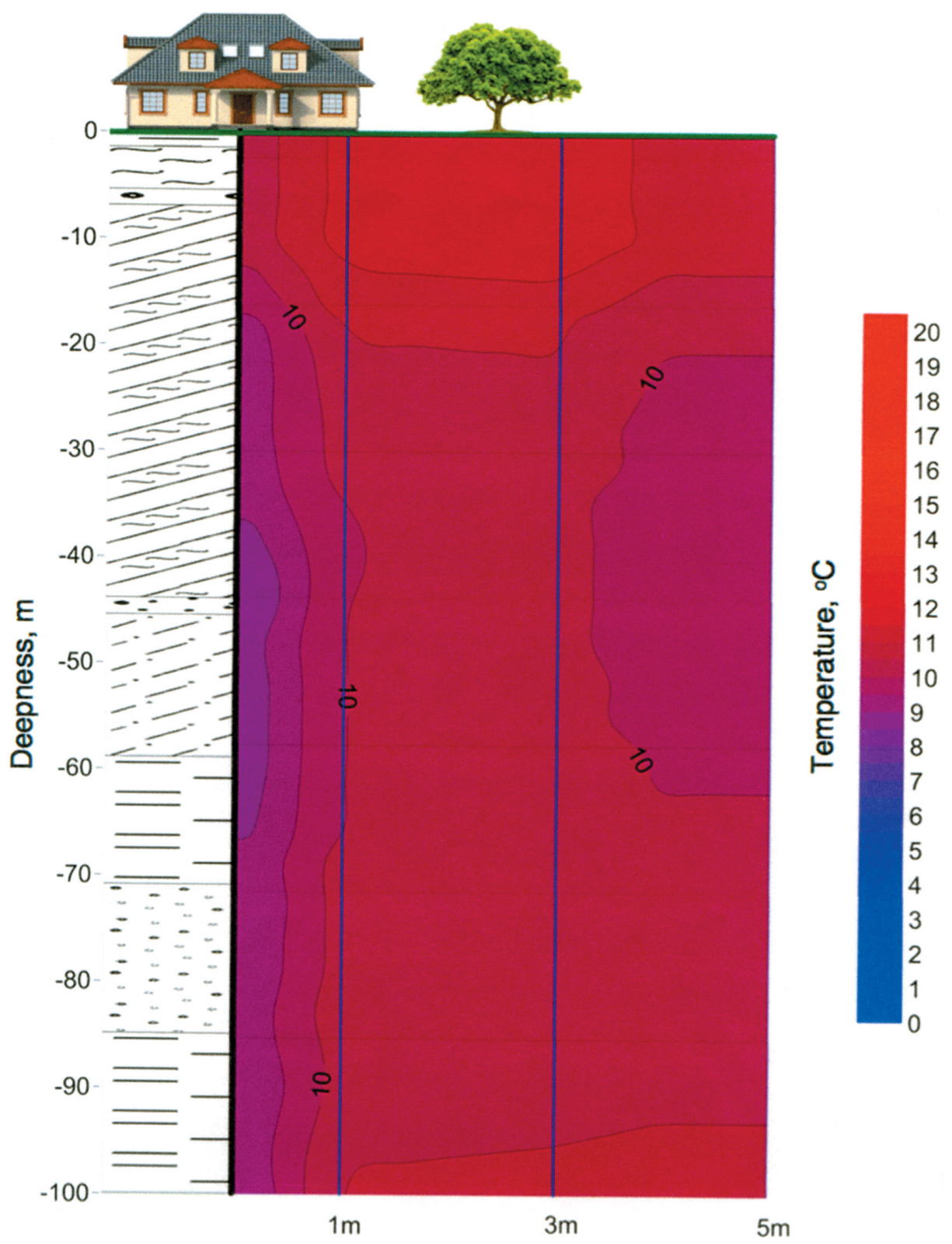

Fig. 9. Rock mass temperature in October 2010

Temperature measurements in boreholes have not indicated any existing pervious layers with such a water flow speed that would influence underground thermal energy storage performance, either. Figures 10 and 11 illustrate rock mass temperature distribution in January and April 2011. 


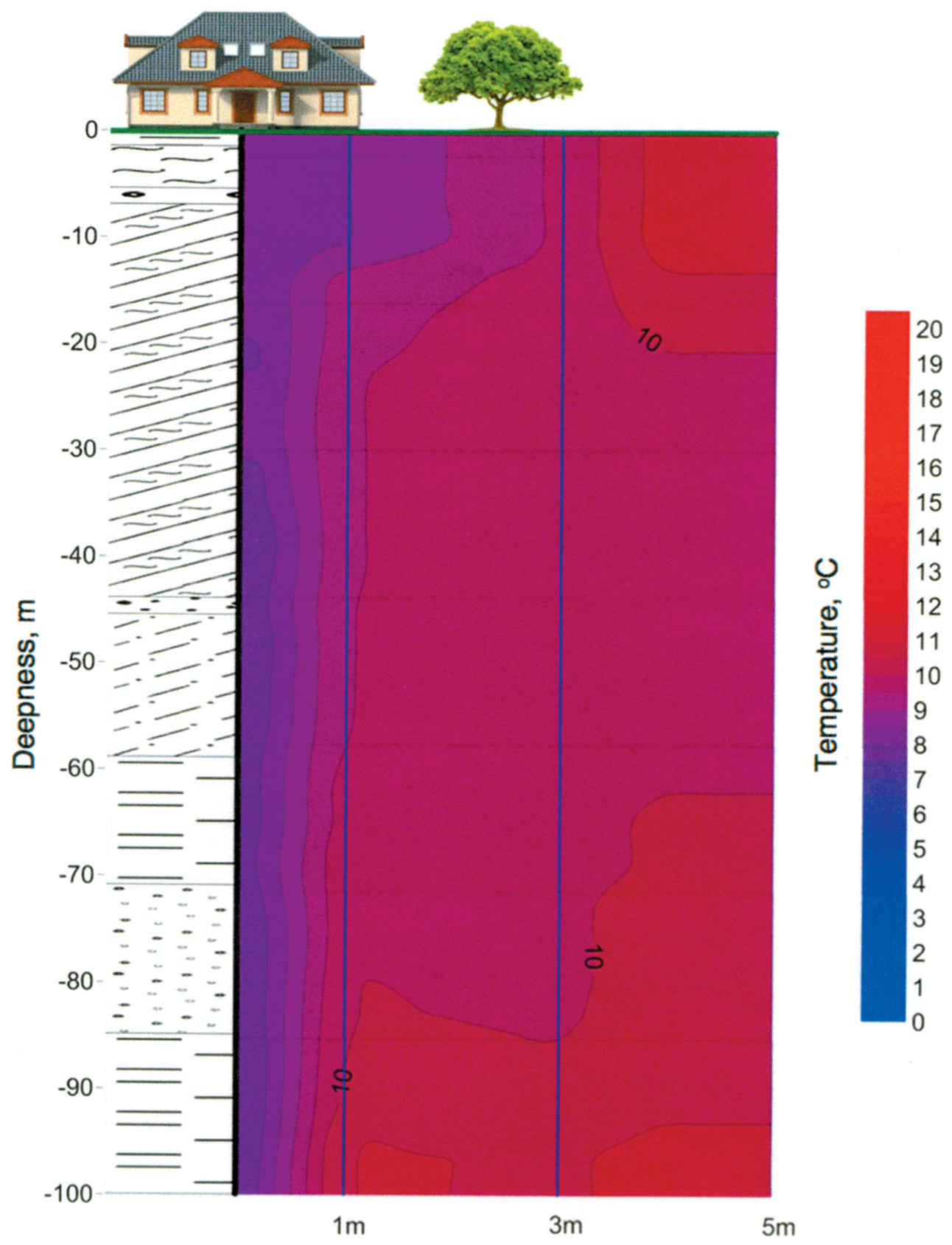

Fig. 10. Rock mass temperature in January 2012 


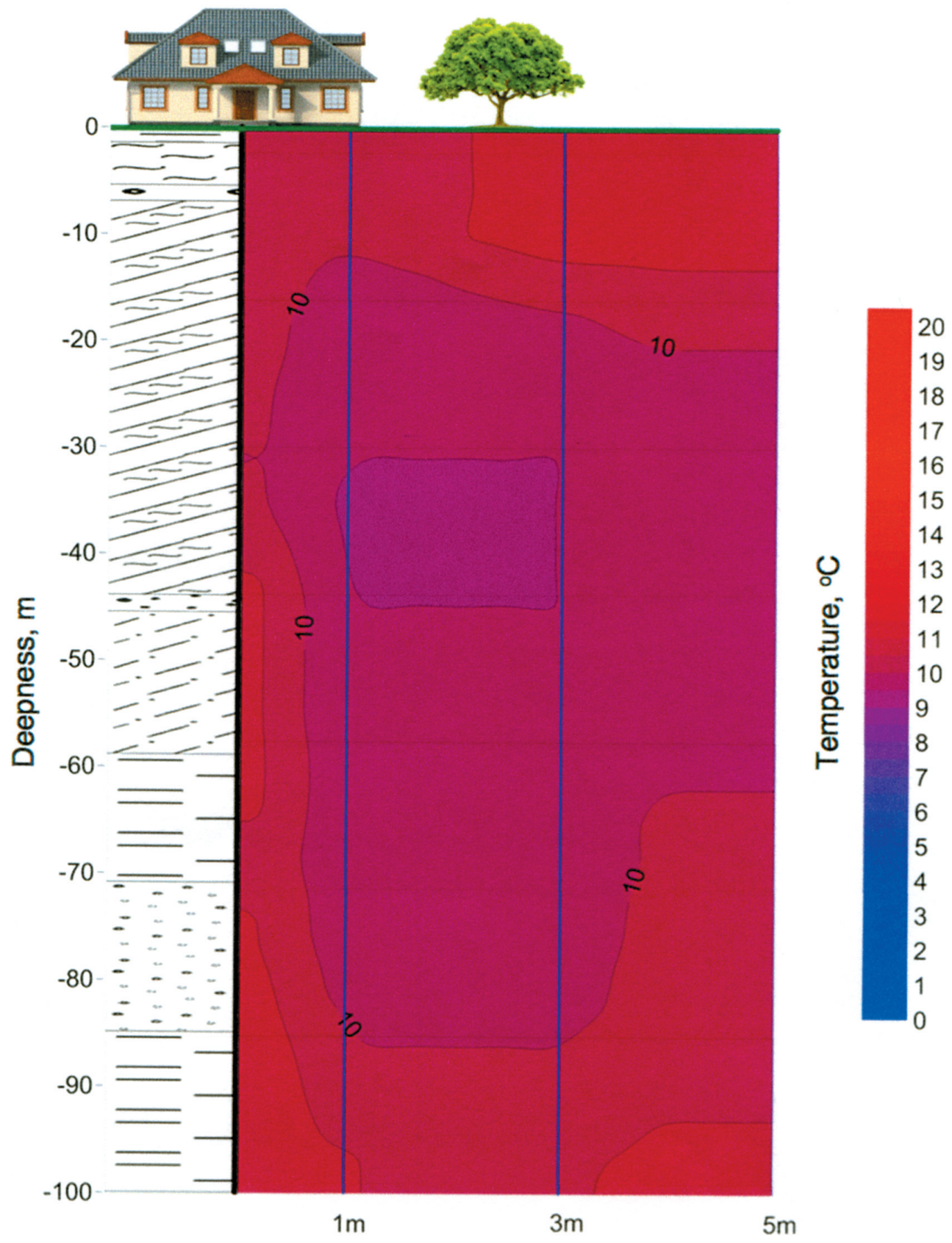

Fig. 11. Rock mass temperature in April 2011 


\section{SIMULATIONS OF UNDERGROUND THERMAL ENERGY STORAGE EXPLOITATION}

Figures 12 and 13 have been attached to illustrate the influence of water filtration on rock mass temperature distribution. They show simulations_of heat transfer carried out for borehole exchangers of Geoenergetics Laboratory of Drilling, Oil and Gas Faculty AGH University of Science and Technology. Figures 12 and 13 on the left side illustrate temperature distribution in UTES when underground water flow occurs and the figures on the right side show UTES when there is no flow.

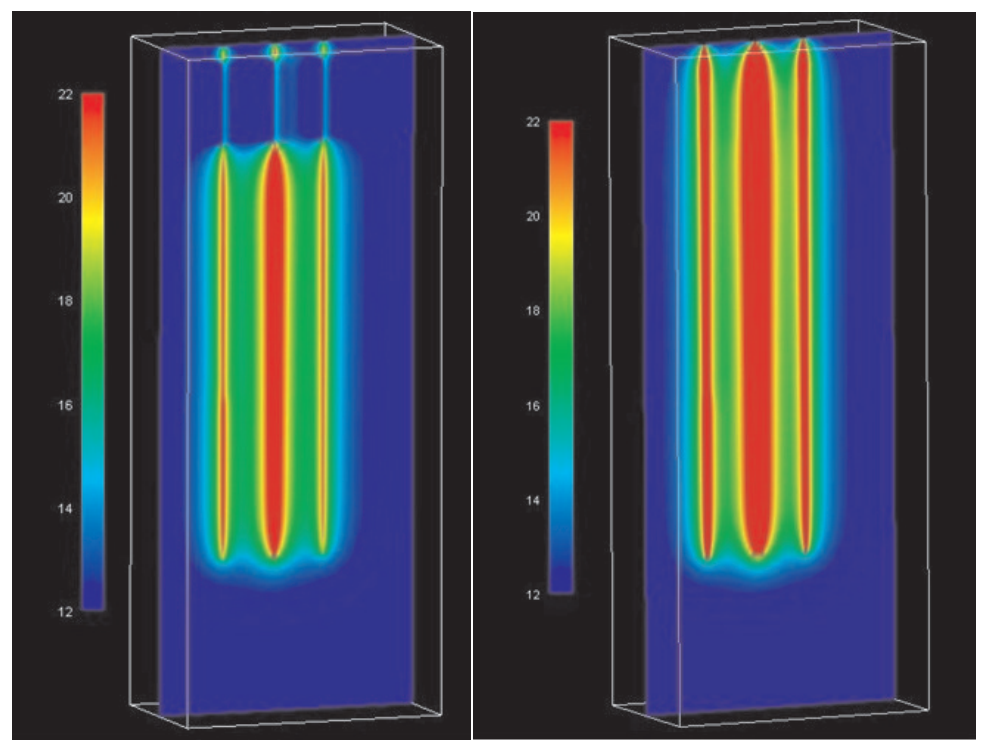

Fig. 12. Temperature distribution during inducting heat into borehole exchangers of Geoenergetics Laboratory of Crilling, Oil and Gas Faculty of AGH; on the right side with no underground water flow, on the left with water flow at the interval of 3-15 MBGL [2]

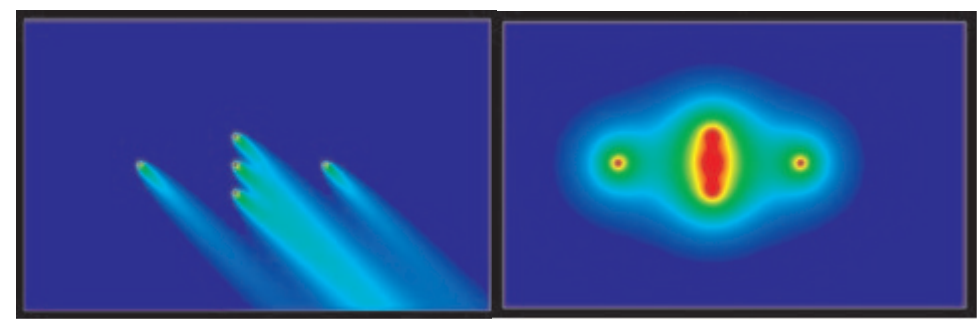

Fig. 13. The horizontal temperature distribution at the deepness of 9 MBGL (the middle of the aquifer) while inducting heat into borehole exchangers of Geoenergetics Laboratory of AGH; on the right side with no underground water flow, on the left with water flow at the interval of 3-15 MBGL [2] 
The chart from Figure 14 illustrates the average temperature that is in particular boreholes in UTES. It can be noticed that at 1-metre distance from a borehole heat exchanger, its influence on rock mass temperature change is insignificant. Temperature in borehole 2 and 5 lacated by BHE's change according seasons. Temperature in boreholes withe the minimum distance 1 meter by $\mathrm{BHE}$ are just constance and change minimally ca. $10^{\circ} \mathrm{C}$.

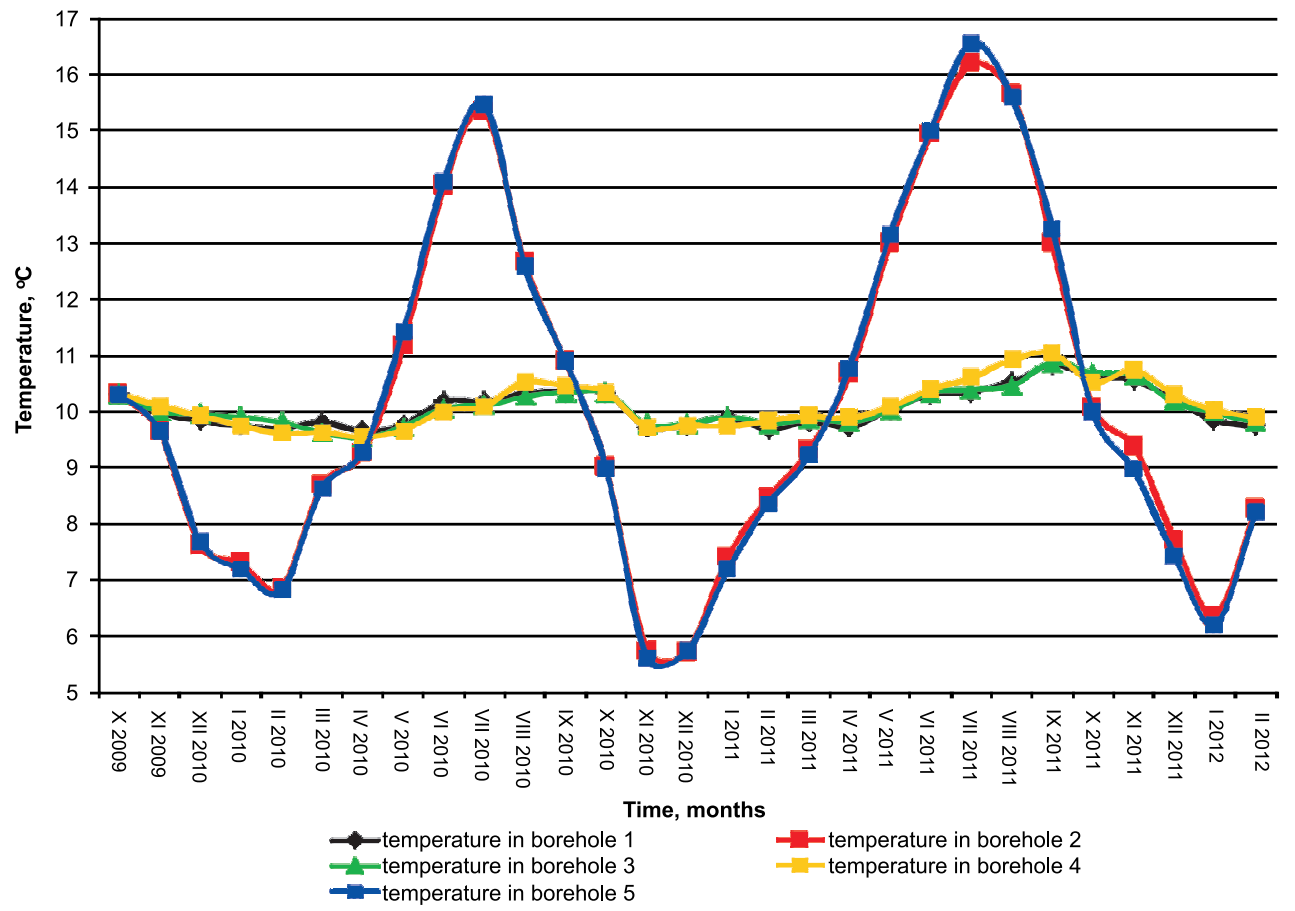

Fig. 14. Temperature variation in five boreholes during UTES exploitation in Łódź

\section{CONCLUSIONS}

1. On the basis of the chart of average temperature in underground thermal energy storage as well as conducted research, it can be inferred that five metres is not too short distance for exchangers operating cyclically in a thermal and cooling mode (Fig. 14). Drilling and placing borehole heat exchangers closer to one another could happen to be risky. Shorter distance would influence system performance in a negative way. For instance, during a longer heating season. It could be possible reaching higher temperature from underground thermal energy storage (UTES) during early months of a heating season. However, rock mass would become cooler and, hence, its performance could be not sufficient at the end of the season. Moreover, the attention ought to be drawn to the fact that during drilling boreholes by a rotating method being used, borehole axis deviation against vertical direction may lead to borehole collision. It would cause a mechanical damage to an already placed borehole exchanger. 
2. On the grounds of the results, it may be stated that slight differences in values of geological layer heat conductance do not have any greater influence on temperature distribution in undergroung thermal energy storage.

3. When underground thermal energy storage functions cyclically in a thermal and cooling mode, deepness of 100 metres for such UTES is not too great. The deeper borehole is, the higher average temperature will be. Higher temperature of a borehole heat exchanger means achieving worse parameters to cool a facility. If there is no balance between the energy taken out from and inducted into rock mass, increased deepness may be beneficial. It will happen when greater amount of heat is taken out from rock mass throughout a year and less heat inducted into it during the summer.

\section{REFERENCES}

[1] Dinçer I., Rosen M.A.: Thermal Energy Storage. Systems and Applications. John Wiley \& Sons, 2011.

[2] Gonet A., Śliwa T., Stryczek S., Sapińska-Śliwa A., Pająk L., Jaszczur M., Złotkowski A.: Metodyka identyfikacji potencjału cieplnego górotworu wraz z technologia wykonywania i eksploatacji otworowych wymienników ciepla [Methodology for the identification of potential heat of the rock mass along with technology implementation and operation of the borehole heat exchangers]. Wydawnictwa AGH, Kraków 2011.

[3] Śliwa T., Gonet A., Skowroński G.: Największa w Polsce instalacja grzewczo-chłodnicza bazujaca na otworowych wymiennikach ciepla [The biggest Polish heating/ cooling installation based on borehole heat exchangers]. Wiertnictwo Nafta Gaz, t. 28, z. 3, 2011, pp. 587-597.

[4] Śliwa T., Kotyza J.: Application of existing wells as ground heat source for heat pumps in Poland. Applied Energy, vol. 74, 2003, pp. 3-8. 